\title{
HOLISTIC APPROACH TO FAIR VALUE ESTIMATION
}

\author{
Justine Jaunzeme \\ Ventspils University of Applied Sciences, Latvia \\ justinej@venta.lv
}

\begin{abstract}
The goal of this paper is to carry out the comparative analysis of the accounting concept of fair value of assets in interconnection with the concepts of value in economics, finance theory, theory of real estate valuation as well as econometrics. The author ascertains that understanding of value differs between the fields of accounting, economics, finance, and real estate valuation. In addition, understanding of the factors, which influence value, differs among these domains. In all mentioned scientific fields, however, common goal is the forecast: "For what a price the asset can be sold at a certain time in a certain market?" In this paper, the author intends to elaborate a holistic approach to fair value concept and to offer more definite and flexible methods for fair value practical estimation. In the empirical part of this paper results of financial statements' research of 31 companies are presented. The methods of research are economic analysis and synthesis, as appropriate to the topic of study chosen.Empirical research leads to conclusions that management of reporting entities apply varied fair value estimation methods to a limited degree. The practice confirms the actual necessity for more holistic approach to the fair value concept and estimation methods.
\end{abstract}

Keywords: fair value, value, finance, economics, econometrics.

\section{Introduction}

Fair value concept in IFRS 13 and FASB 820. Fair value in one of the most discussable measurement bases applied according to the International Financial Reporting Standards (IFRS - in abbreviation). Fair value concept and its determination are explained in the IFRS 13 "Fair value measurement". IFRS 13 defines fair value as the price that would be received to sell an asset or paid to transfer a liability in an orderly transaction between market participants at the measurement date [1].

As a result of convergence between the IFRS and the U.S. Generally Accepted Accounting Principles (GAAP - in abbreviation), disparities between fair value definitions found in IFRS 13 "Fair Value Measurement" and the U.S. Financial accounting standards board's (FASB - in abbreviation) standard 820 "Fair Value Measurement" have been minimized. In comparison to the IFRS, the U.S. FASB standard 820 "Fair Value Measurement" provides a more extensive definition of fair value. According to the U.S. FASB standard 820 "Fair Value Measurement, "fair value is the price that would be received to sell an asset or paid to transfer a liability in an orderly transaction in the principal (or most advantageous) market at the measurement date under current market conditions (that is, an exit price) regardless of whether that price is directly observable or estimated using another valuation technique" [2].

The applications and importance of fair value concept and measurement. There are multivariate applications of fair value measurement according to the IFRS. For most of real assets fair value measurement is an alternative according to the IFRS. After initial recognition, the reporting entity may choose between the cost model and revaluation model for property, plant and equipment and intangible assets. If the revaluation model is applied, items of property, plant and equipment and intangible assets are measured at fair value on the balance sheet. Investment property may be carried at either cost model, or fair value model on the balance sheet. Measurement of biological assets and agricultural produce at fair value less estimated costs to sell is compulsory unless fair value of these assets cannot be estimated reliably.

Baseline of current research. These two respectable definitions of fair value (IFRS 13 and FASB 820), scientific publications about the fair value concept, applications and importance, as well as observed estimation practice are the starting points to wide research provided by the author for the reporting years of 2017, year ended 30 June 2018, and 18 months ended 30 October 2018 in order to investigate strong and week aspects of fair value definitions given in IFRS 13 and FASB 820 . The most topical is the fact established by the author of surprising disassociation among theoretical platform of IFRS and FASB and economics, which deeply discovers the genesis of the value concept and price formation depending on market attributes (by opinion of the author, especially important it is to study the asset valuation process by potential buyers during auction), and the finance theory, where diversification and assets' portfolio price forecasts have attained noteworthy results, and the theory of 
real estate valuation, where professional methods of assets' market prices' estimation are elaborated. In the IASB and FASB publications the author has not encountered econometric models for estimation of fair value either. Econometrics, however, allows discovering of useful latent information from statistical data.

The goal of this research is to carry out the comparative analysis of the accounting concept of fair value of assets in interconnection with the concepts of value in economics, finance theory, theory of real estate valuation as well as econometrics in order to elaborate holistic approach to the understanding of the concept of fair value of assets and holistic approach to the fair value estimation methods. It seems absolutely logical and fruitful, because in all mentioned scientific fields a common goal is the forecast: "For what price the given asset can be sold at a certain time in a certain market?" The empirical research reported in this paper confirms the actual necessity for more holistic practical approach to the fair value concept and estimation methods.

Some notes about fair value in IFRS 13. Fair value shall be estimated as a market price in an orderly sales transaction. IFRS 13 defines an orderly transaction as "a transaction that assumes exposure to the market for a period before the measurement date to allow for marketing activities that are usual and customary for transactions involving such assets or liabilities; it is not a forced transaction." Orderly transactions exclude transactions that are forced or liquidation sale.

This definition includes two key components:

1. adequate market exposure is required in order to provide market participants with the ability to gain an awareness and knowledge of the asset or liability necessary for a market-based exchange;

2. the transaction should involve market participants that, while being motivated to transact for the asset or liability, are not compelled to do so [2].

Following Ernst \& Young (2012), circumstances that may indicate that a transaction is not orderly include the following:

1. there was not adequate exposure to the market for a period before the measurement date to allow for marketing activities that are usual and customary for transactions involving such assets or liabilities under current market conditions,

2. there was a usual and customary marketing period, but the seller marketed the asset or liability to a single market participant,

3. the seller is in or near bankruptcy or receivership (which means that the seller is distressed) [3].

Fair value is the price that would be received to sell an asset or paid to transfer a liability regardless of whether that price is directly observable or estimated using another valuation technique. Thus, if no sales transaction has actually taken place, fair value is estimated as a hypothetical market price, that is market price, which would be observed, if sales transaction would have taken place. Observed market prices, however, are preferred to hypothetical, estimated market prices as measures of fair value.

Publications about economic support for fair value measurement. J.P. Jones and S.D. Stanwick (1999), C.Cuningham (2004), and W.P.Schuetze (2006) consider measurement of all assets at their fair values. The authors argue that users of financial statements would receive a more relevant information, if all assets would be measured at fair value [4-6].

"In order for financial information to be relevant for investors, creditors and agencies which rate companies the fair values must replace historical costs of both assets and liabilities," W.P.Schuetze (2006) writes [16]. In the opinion of J.P. Jones and S.D. Stanwick (1999), investors and creditors are provided with the information that is necessary for decision making, if assets are carried at their fair values. J.P. Jones and S.D. Stanwick (1999) argue that both investors and creditors base their decisions on the market values of assets. These authors hold and opinion that fair values of assets are relevant, if they represent the assets' market values [4].

"Fifty years ago nobody could even imagine that the main resources to be used in production of goods and rendering of services will be concepts and ideas, not natural resources and physical labour," the president of the U.S. Federal Reserve A.Greenspan emphasizes. Since the influence of concepts and ideas on companies' market value over last fifty years has substantially increased, a necessity has arisen to measure these companies' main resources in order to ensure that financial statements are 
useful to investors in economic decision-making. Assets' measurement at fair values is a potential solution.

If fair values of assets and liabilities are disclosed in the financial statements, the management of companies may better evaluate the work of management. Increase in assets' fair values and decrease in liabilities' fair values indicate that the management of companies works in the interest of companies' owners - in order to increase the market value of the company. If assets and liabilities are measured at their historical costs, the owners of the company do not have an opportunity to monitor the quality of the management's work. J.Woolfe (2007) therefore argues that the presentation of assets' and liabilities' fair values in the financial statements motivates the management of companies to improve their work quality [7].

A. Madhavan (2002) mentions the fact that disclosure of assets' fair values in financial statements leads to the decrease in speculation with the asset under concern as an argument of assets' fair value presentation. As the amount of speculative dealings decreases, the freed resources may be invested in production and rendering of services [8].

Conclusion about accounting theory. The author ascertains that the understanding of a fair value differs between the theories of economics, finance, real estate valuation theory, econometrics and accounting theory. Furthermore, consideration for factors, which influence fair value, is not the same in all scientific domains. For example, in accounting forms of market organization - perfect competition, monopolistic competition, oligopoly and monopoly, which influence the formation of assets' prices, are neglected. No consideration for auctions, which reveal fair values of assets, is provided for in financial reporting. As financial statements are prepared, no use is made out of econometric methods, which are suitable for the sake of identification of statistically relevant factors and for quantification of these factors' influence on the dependent variable. In all scientific fields, however, a common goal is the forecast: "For what a price the asset can be sold at a certain time in a certain market?"

It can be concluded that the fair value concept in the accounting theory is not integrated with the fields of economics, finance, econometrics and real estate valuation. The task that remains is to study practical fair value estimation methods of companies in order to investigate whether valuation models found in economics, finance, econometrics, and real estate valuation have been applied in practice.

During the research, the author has not encountered studies on application of valuation models found in economics, finance and econometrics in accounting practice yet.

\section{Materials and methods}

In the empirical part of this paper financial statements of 31 Latvian, Lithuanian and Estonian companies, which are listed on the NASDAQ regulated market's Main List, are studied in order to learn whether these companies have selected revaluation model in accounting for their property, plant, equipment and intangible assets and fair value model in accounting for their investment property. Also, valuation methods chosen in accounting for biological assets and agricultural produce are studied. For companies that have chosen to carry their assets at fair value, the methods applied for estimation of fair value are researched. As part of the research, the accordance of practically applied methods of fair value estimation to value concepts in economics, finance and econometrics is studied.

The methods of the research are economic analysis and synthesis, as appropriate to the topic of the study chosen.

Fair value in accounting as compared to value in economics, finance and econometrics. In order to elucidate the fair value concept, the value theory in economics and finance should be examined and compared to the fair value concept in financial reporting. Substantial contribution to the elaboration of the value concept in economics has been provided by Adam Smith (1723-1790), David Ricardo (17721823), Karl Marx (1818-1883), Antoine Augustin Cournot (1801-1877), Alfred Marshall (1842-1924), Irwing Fisher (1867-1947), John Maynard Keynes (1883-1946), Gérard Debreu (1921-2004), and several other distinguished economists. Notable value theories in economics is value as a market price, classical capital theory (value as a present value of discounted cash flows), and the labour theory of value. By opinion of the author, a sufficient role to estimate the fair value of asset can be played by the auctions. 
Classical capital theory was authored by U.S. economist Irwing Fisher (1867-1947). The work of Irwing Fisher "Nature of Capital and Income," first published in 1906, is dedicated to this theory. The core concepts of the classical capital theory are the concepts of capital and its fundamental value: "The value of an asset always equals the future cash flow discounted at opportunity cost of capital." Stock of wealth, which exists at a given moment and which is expected to generate economic benefits in the future is defined as capital. Economic benefits normally are measured in monetary terms. Fundamental value of capital is the present value of the cash flows, which are expected to be generated by the capital stock, discounted at the opportunity cost of capital [9]. Nobel Prize winners in Economics Miller and Modigliani applied the idea of Irving Fisher in their book "How does the firm cost? [10]"

Alfred Marshall (1890) offers a definition of value, which is based on exchange of goods: "Value of a good, expressed in terms of other goods' quantity at certain time and place, is the quantity of other goods, for which one unit of first good can be exchanged. Therefore, the concept of value is relative and expresses the relationship between two goods at certain time and place. [11]" The value of good stated in monetary terms is the price of this good that is denominated in certain currency. Economic theory studies how equilibrium value of a good is formed not only when exchange between two consumers takes place, but also when consumption possibilities are limited by consumers' budget or production possibilities. Frank Milne (1995) in his famous book "Finance Theory and Asset Pricing" demonstrates the genesis of value in case of pure exchange with a single consumer, in case of pure exchange with two consumers and in the case of consumption and production:

1. Pure Exchange: Single consumer. The supporting prices depend upon the endowment and the utility function. Change either and you change the prices.

2. Pure Exchange: Two Consumers. Now the prices and consumption allocations depend upon the preferences and endowments of both consumers. By altering the division of the aggregate endowment, the competitive allocations and prices will change (in general).

3. Consumption and Production. All of the endowment is used as an input to produce contingent production. This contingent production is consumed [12].

The author is of a strong opinion that these classical fundamental ideas about value genesis must be included in the assets' fair value theory.

Exchange of goods takes place in a market; equilibrium price of a good represents its value. According to the modern economic theory, the price of a good forms depending on the structure of the market, in which the exchange takes place. Economics widely studies four market forms - perfect or pure competition, monopolistic competition, oligopoly, and monopoly. The price of the same good in a market of perfect competition may differ from its price in a monopolistic market.

In the economic theory the labour theory of value plays a special role. Adam Smith, David Ricardo, and Karl Marx are the founders of the labour theory of value [13-15]. It is important to remark that later the labour theory value is corroborated by the input-output theory of Wassily Leontief (1936) [17]. According to the labour theory of value, the value of an item is represented by all labour that is beneficial to society and is embodied into this item. From the input-output model follows that in a perfect competition of products and resources markets environment in a long term economic profits of each firm equals zero and prices are equal the total labour costs.

Furthermore, econometric models may be applied for determination of fair value. Justine Jaunzeme (2015) in her paper demonstrates how fair value of real estate can be estimated by means of an econometric model, where the age of the real estate, the material from which it is built, area and location of property are selected as independent variables and estimated market value of property as dependent variables [18].

\section{Results and discussion}

Analysis of Latvian listed companies' financial statements. Notes to the financial statements for the year ended 31 December 2017 of 3 Latvian listed companies as well as the notes to the financial statements for the year ended 30 June 2018 of 1 Latvian listed company were studied.

The author found that all 4 companies chose the cost model for its intangible assets. 3 companies out of 4 companies chose the cost model for the property, plant and equipment. 1 company out of 4 companies studied chose the revaluation model for the property, plant and equipment - land and 
buildings; and fair value of the land and buildings was determined by independent experts according to depreciated replacement cost approach.

2 companies out of 4 companies studied carry investment property on their balance sheet. 1 out of these 2 companies establishes fair value of investment property by hiring independent experts.

Analysis of Lithuanian listed companies' financial statements. Notes to the financial statements for the year ended 31 December 2017 of 12 Lithuanian listed companies as well as the notes to the financial statements for the year ended 30 June 2018 of 1 Lithuanian listed company were studied.

12 companies out of 13 companies studied have selected the cost model for their intangible assets. 1 company of 13 companies researched values of their intangible assets according to the cost model except for emission allowances, which are revalued at fair value using the active market prices.

7 companies out of 13 companies researched value of their property, plant and equipment according to the cost model on the balance sheet. 5 companies measure their property, plant and equipment, except some items, at cost less accumulated depreciation, less accumulated impairment losses on the balance sheet. 4 of these companies measure all items of property, plant and equipment according to the cost model except for real estate - land and buildings, which are valued in accordance with the revaluation model. Three companies report that fair value of property, plant and equipment is determined by qualified independent valuators:

"Land comprises mainly agricultural land and is shown at revalued amounts based on periodic, but at least triennial, valuations by external independent valuers."

"Property, plant and equipment is shown at revalued amount based on periodic valuations by external independent valuers, less subsequent accumulated depreciation and impairment, except for gas distribution pipelines and their equipment, gas technological equipment and structures that are accounted for under the cost method."

"Property, plant and equipment, which includes the categories of assets of hydro power plant, pumped storage power plant, combined cycle unit and reserve power plant, are accounted for at cost less accumulated depreciation and impairment. Other property, plant and equipment are shown at revalued amounts, based on periodic (at least every 5 years) valuations performed by independent valuers, less subsequent accumulated depreciation and subsequent accumulated impairment losses."

One Lithuanian company reports having measured all property, plant and equipment at revalued amounts. In its notes the company reports: "The valuation of property, plant and equipment, except for motor vehicles, at the Group and the Company as at 31 December 2015 was conducted by independent property valuer Ober-Haus UAB. The fair value estimation was based on the comparable sales price method. The valuation of other categories of assets was based on the replacement cost method. The valuation of motor vehicles was conducted by the Company's experts, who established the fair value using the comparable sales price method."

5 companies out of 13 companies studied report investment property on the balance sheet. 4 of these companies, which carry investment properties, value them according to the cost model, and 1 company has selected the fair value model for its investment property.

2 Lithuanian agricultural companies out of 13 companies studied report biological assets on the balance sheet. Biological assets are measured at fair value less estimated costs to sell. "If an active market exists for a biological asset or agricultural produce, the quoted price in that market is the appropriate basis for determining the fair value of that asset. If an active market does not exist, the most recent market transaction price, provided that there has not been a significant change in economic circumstances between the date of that transaction and the balance sheet date, is used in determining fair value. Cost is used as an approximation of fair value, when little biological transformation has taken place since initial cost incurrence, e.g. within short time after seeding the crop or mushroom. During the growth period (crops, mushrooms, livestock until the 1st lactation period), costs are capitalized to the carrying value of the asset. At each balance sheet date the biological assets are revalued to their fair value," 1 agricultural company states in the notes to its financial statements.

“The Group's biological assets include animals and livestock, poultry and crops. Animals and livestock are accounted for at fair value less costs to sell. The fair value of milking cows is measured 
using the discounted cash flows method (level 3). Other livestock is measured at comparable market prices (level 2). Poultry is accounted for at fair value less costs to sell. The fair value of poultry is measured based on future value of chickens/meat broilers/eggs less costs to maintain (level 3). Crops are accounted for at fair value less costs to sell. The fair value of crops is measured at comparable market prices based on expected yield (level 3). Agricultural produce harvested from an entity's biological assets is measured at its fair value less estimated costs to sell at the point of harvest," other Lithuanian agricultural company states in its notes to the financial statements, emphasizing the application of comparable market and discounted cash flows methods.

Analysis of Estonian listed companies' financial statements. Notes to the financial statements for the year ended 31 December 2017 of 14 Estonian listed companies as well as the notes to the financial statements for 18 months ended 31 October 2018 of 1 Estonian listed company were studied.

13 companies out of 14 companies, which carry intangible assets on the balance sheet, value intangible assets according to the cost model. One company measures intangible assets, except trademarks, at historical cost less accumulated depreciation and accumulated impairment losses; while trademarks are recognized in the balance sheet at fair value less any accumulated amortization.

10 out of 14 companies, which carry property, plant and equipment on the balance sheet, value the items of property, plant and equipment at cost less accumulated depreciation and accumulated impairment losses. 4 out of 14 companies measure part of the property according to the revaluation model. 2 companies measure all property, plant and equipment following the cost model, except for land and buildings, which are measured at fair value according to the revaluation model. One company reports that their land and buildings are valued by independent real estate experts.

One Estonian company values property, plant and equipment at historical cost less depreciation, except for certain warehouse equipment and buildings, which are revalued at fair value. Buildings and warehouse equipment are recognized at fair value based on periodic, but at least triennial, valuations by external independent valuers, less subsequent depreciation.

Estonian maritime transport company values property, plant and equipment at cost less accumulated depreciation and accumulated impairment losses except for ships, which are measured at fair value. "The fair value of ships depends on many factors, including the year of construction, several technical parameters as well as how the ships have been maintained (i.e. how much the owner has invested in maintenance). In order to assess the fair value of ships the Group's management used independent appraisers," the Maritime company states in the notes to its financial statements.

9 out of 15 companies, which financial statements were studied, carry investment properties on the balance sheet. 7 out of 9 companies value investment properties at fair value, while the rest 2 companies measure investment properties according to the cost model. 5 companies report that fair value was estimated by an independent appraiser. 3 companies report the application of the discounted cash flow model for the purpose of fair value estimation.

"Independent expert valuation as to the fair value of investment property is based on the following: - Rental income: real growth rates and rents under current lease agreements are used; Vacancy rate: the actual vacancy rate of the investment properties, taking into account the risks associated with the property; - Discount rate: calculated using the weighted average cost of capital (WACC) associated with the investment property; - Capitalization rate: based on the estimated level of return at the end of the estimated holding period, taking into consideration the forecasted market condition and risks associated with the property," application of the discounted cash flow model is explained in the notes to the financial statements of one company.

1 company reports - the usage of the market comparables' model, while 3 companies report in the notes to the financial statements that both the discounted cash flow and market comparables' models have been applied.

1 Estonian fishing company reports fish stocks as biological assets on the balance sheet. Fish stocks are classified as fries, juveniles and fish suitable for harvesting. "Fries are carried at fair value. Fair value is determined on the basis of the biomass volume of fry and its weighted average market price at the balance sheet date. The fair value of juveniles cannot be determined reliably due to the absence of an active market, and they are carried in the statement of financial position at cost. On initial recognition (at acquisition or reclassification from juveniles) and at each balance sheet date the 
fish suitable for harvesting are measured at their fair value less estimated costs to sell. The basis for determination of fair value is the estimated biomass of fish suitable for harvesting, less the weight loss occurring at disposal, and the weighted average market price at the balance sheet date, i.e. the latest market price for similar assets sold by independent parties, adjusted for the effect of existing differences, assuming no major changes have occurred in the economic environment between the transaction date and the balance sheet date," valuation of fish is explained in the notes to the financial statements of this fishing company.

Summary of empirical research. The results of the research are summarized in Table 1.

Table 1

Voluntary choice of fair value measurement in accounting for intangible assets, property, plant, equipment and investment property at public Latvian, Lithuanian and Estonian companies in 2017

\begin{tabular}{|c|c|c|c|c|}
\hline \multicolumn{2}{|c|}{ Companies } & $\begin{array}{c}\text { Intangible } \\
\text { assets }\end{array}$ & $\begin{array}{l}\text { Property, plant } \\
\text { and equipment }\end{array}$ & $\begin{array}{l}\text { Investment } \\
\text { property }\end{array}$ \\
\hline \multirow{2}{*}{$\begin{array}{l}\text { Latvian } \\
\text { companies }\end{array}$} & $\begin{array}{c}\text { number of companies } \\
\text { which measure at fair } \\
\text { value }\end{array}$ & 0 out of 4 & 1 out of 4 & 1 out of 2 \\
\hline & $\begin{array}{c}\text { percentage of } \\
\text { companies which } \\
\text { measure at fair value }\end{array}$ & $0 \%$ & $25 \%$ & $50 \%$ \\
\hline \multirow{2}{*}{$\begin{array}{l}\text { Lithuanian } \\
\text { companies }\end{array}$} & $\begin{array}{c}\text { number of companies } \\
\text { which measure at fair } \\
\text { value }\end{array}$ & 0 out of $13^{*}$ & 6 out of $13 * *$ & 1 out of 5 \\
\hline & $\begin{array}{c}\text { percentage of } \\
\text { companies which } \\
\text { measure at fair value }\end{array}$ & $0 \%$ & $46 \%$ & $20 \%$ \\
\hline \multirow{2}{*}{$\begin{array}{l}\text { Estonian } \\
\text { companies }\end{array}$} & $\begin{array}{c}\text { number of companies } \\
\text { which measure at fair } \\
\text { value }\end{array}$ & 0 out of $14 * * *$ & 4 out of $14 * * * *$ & 7 out of 9 \\
\hline & $\begin{array}{c}\text { percentage of } \\
\text { companies which } \\
\text { measure at fair value }\end{array}$ & $0 \%$ & $\begin{array}{c}\text { approximately } \\
29 \%\end{array}$ & $\begin{array}{c}\text { approximately } \\
78 \%\end{array}$ \\
\hline \multirow{2}{*}{ In total } & $\begin{array}{c}\text { number of companies } \\
\text { which measure at fair } \\
\text { value }\end{array}$ & 0 out of 31 & 11 out of 31 & 9 out of 16 \\
\hline & $\begin{array}{c}\text { percentage of } \\
\text { companies which } \\
\text { measure at fair value }\end{array}$ & $0 \%$ & $35 \%$ & $56 \%$ \\
\hline
\end{tabular}

*except for emission rights.

** 4 Lithuanian companies measure all items of property, plant and equipment except for land and buildings at cost less accumulated depreciation, less accumulated impairment losses on the balance sheet. Land and buildings are carried at fair value.

*** At one Estonian company trademarks with finite useful lives are recognized in the balance sheet at fair value less any accumulated amortization. Other intangible assets (including computer software) are stated in the balance sheet at historical cost less any accumulated amortization and any impairment losses.

**** At one Estonian company property, plant and equipment, except ships, are measured at cost, less accumulated depreciation and any impairment. Ships are measured at revalued amounts (i.e. fair value less depreciation charged subsequent to the date of the revaluation).

The research findings indicate that voluntary choice of fair value measurement is more common for investment property than for property, plant and equipment and intangible assets. As far as property, plant and equipment are concerned, it is more common to measure land and buildings than other assets at fair value. Furthermore, revaluation of property, plant and equipment to their fair value is more common among Lithuanian companies than at Latvian and Estonian companies. 
Valuation methods applied. The methods which the Baltic companies apply for fair value measurement are summarized in Table 2.

\section{Methods applied for fair value measurement by Latvian, Lithuanian and Estonian listed companies in 2017}

\begin{tabular}{|c|c|c|c|c|}
\hline Methods & $\begin{array}{c}\text { Intangible } \\
\text { assets }\end{array}$ & $\begin{array}{c}\text { Property, plant } \\
\text { and equipment }\end{array}$ & $\begin{array}{c}\text { Investment } \\
\text { property }\end{array}$ & $\begin{array}{c}\text { Biological } \\
\text { assets }\end{array}$ \\
\hline $\begin{array}{c}\text { Discounted cash flow } \\
\text { method }\end{array}$ & - & - & 6 & 1 \\
\hline $\begin{array}{c}\text { Market comparables } \\
\text { method }\end{array}$ & - & 1 & 4 & 2 \\
\hline $\begin{array}{c}\text { Depreciated } \\
\text { replacement cost }\end{array}$ & - & 1 & - & - \\
\hline Replacement cost & - & 1 & - & - \\
\hline $\begin{array}{c}\text { Reference to active } \\
\text { market prices }\end{array}$ & 1 & - & - & - \\
\hline
\end{tabular}

The discounted cash flow method is the most popular method for determination of investment properties' fair value at the Baltic listed companies. It should be noted that this method corresponds to the classical capital theory authored by Irwing Fisher (1867-1947).According to the classical capital theory the value of an asset always equals the future cash flow discounted at opportunity cost of capital.

The link between the market comparables' method and concept of active marked prices applied in accounting practice and economic theory of market price formation, however, is missing according to the results of the empirical research. It also must be emphasized that econometric methods, which are widely used in economics' research, are not applied in accounting practice.

\section{Conclusions}

There is a wide gap between the theory of accounting and economics, finance and econometrics with respect to fair value estimation.

Also, the empirical research leads to conclusions that management of reporting entities do not apply econometric methods and apply economic methods of fair value estimation to a limited degree. As an exception, the discounted cash flow model, which has been applied for investment properties' fair value estimation, conforms to the classical capital theory developed by Irwing Fisher (1867-1947).

The practice confirms the actual necessity for more holistic approach to the fair value concept and estimation methods. The author of this paper calls for application of econometric methods and economic models of market price formation in accounting practice of fair value estimation.

\section{References}

[1] Financial Accounting Standards Board. U.S. FASB standard 820 "Fair Value Measurement." Norwalk, Co: FASB, 2011

[2] International Accounting Standards Board. IFRS 13 "Fair Value Measurement." London: IASB, 2011.

[3] Ernst \& Young. Applying IFRS. IFRS 13 Fair Value Measurement. Ernst \& Young, 2012, 195 p.

[4] Jones J.P., Stanwick S.D. Fair value accounting: a guide to understanding the current standards. The Journal of Corporate Accounting and Finance/Autumn 1999, 1999, pp. 103-108.

[5] Cunningham C. Fair Value Accounting: Fair for Whom? Financial Executive, March/April, 2004, pp. 22-31.

[6] Schuetze W.P. In defense of fair value. The CPA Journal Online, 2006, pp. 11-12.

[7] Woolfe J. EU agonizes over fair value. Accounting Today, Issue July 23, 2007. [online] [04.09.2011.] Available at: www.accountingtoday.com/ato_issues/2007_13/24796-1.html

[8] Madhavan A. Implementing fair value pricing. The Journal of Investing, Vol. 13, No. 1, 2004, pp. 14-22. 
[9] Fisher I. The Nature of Capital and Income. New York: The Macmillan Company, 1906, 427 p. [online] [20.08.2011] Available at: http://books.google.lv

[10] МодильяниФ., МиллерМ. Сколькостоитфирма? TеоремаММ. (How much does the firm cost? M\&M theorem). Переводсанглийского. АкадемиянародногохозяйстваприПравительстве Российской Федерации. - Москва: Дело, 2001. ISBN 5-7749-0152-1

[11] Marshall A. Principles of Economics. London: Macmillan, 1890.

[12] Milne F. Finance Theory and Asset Pricing. Oxford: Clarendon Press: Oxford, 1995, 128 pages.

[13] Markss K. Darba alga, cena un peḷna (Wage, price and profit). Riga: Latvijas valsts izdevniecība, 1956, 67 pages. (in Latvian)

[14] Ricardo D. On the Principles of Political Economy and Taxation. London: John Murray, 1817. [online] [15.09.2011.] Available at: www.econlib.org/library/Ricardo/ricP.html

[15] Smith A.An Inquiry into the Nature and Causes of the Wealth of Nations. Edited by Sálvio M. Soares. MetaLibri, 2007. [online] [15.09.2011] Available at: http://metalibri.wikidot.com/title:aninquiry-into-the-nature-and-causes-of-the-wealth-of

[16] ЛеонтьевВ. Экономические эссе (Economic Essay). Москва: Издательство политической литературы. 1990. 415 pages.

[17] Jaunzeme J.S. Apartments' Fair Value Estimate. Proceedings of International Scientific Conference of Daugavpils University, Issue 57, 2015, pp. 6-12 